\title{
Polyarteritis nodosa: an atypical presentation
}

\author{
Carina Alexandra dos Santos Andrade, ${ }^{1}$ Alexandre Vasconcelos, ${ }^{1}$ João Correia Pinto ${ }^{2}$
}

${ }^{1}$ Internal Medicine Department, Hospital Pedro Hispano, Matosinhos, Portugal ${ }^{2}$ Pathology Department, Hospital Pedro Hispano, Senhora da Hora, Portugal

\section{Correspondence to}

Dr Carina Alexandra dos Santos Andrade,

carina82andrade@gmail.com

Accepted 19 February 2015

\section{DESCRIPTION}

Polyarteritis nodosa is a systemic necrotising vasculitis involving the small and medium arteries. Men aged between 40 and 60 years are more frequently affected and histological evidence of vasculitis in the involved organs is necessary for diagnosis. ${ }^{12}$

A 55-year-old woman presented with a history of fever and painful skin lesions in the right leg, associated with progressive weakness and sensory loss in the affected limb.

Physical examination revealed multiple hypochromic spots over the face and limbs (figure 1), a rounded lesion with a necrotic centre and inflammatory broadsides on the right knee (figure 2), and two haemorrhagic bullous lesions on the right foot (figure 3). These lesions were associated with swelling, redness and warmth of the right limb. A distal paresis of the right limb, absence of right ankle reflex, decreased vibratory sensation and hypoesthesia below the right knee were observed during neurological examination.

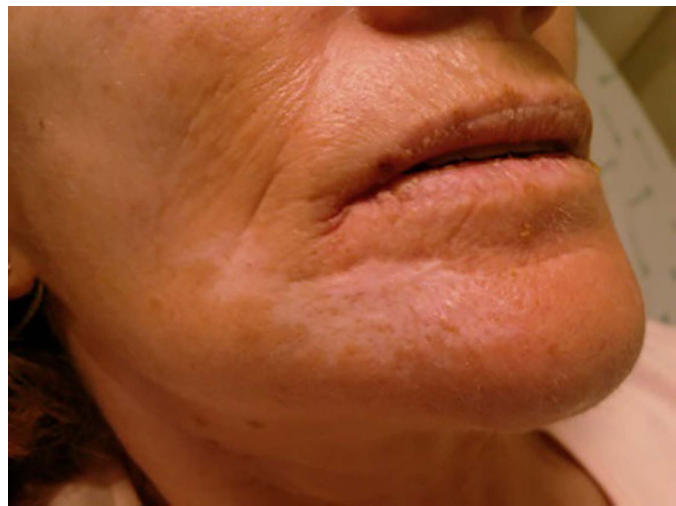

Figure 1 Hypochromic spots over the face.

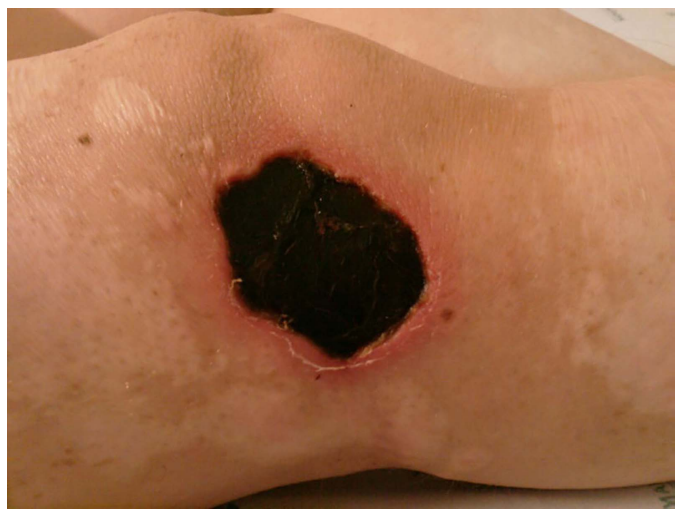

Figure 2 Rounded lesion with a necrotic centre and inflammatory broadsides. Hypochromic spots similar to those on the face are also present.

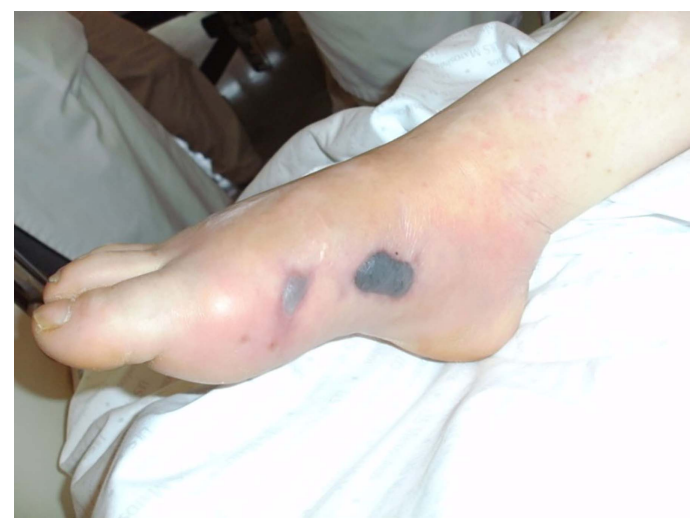

Figure 3 Haemorrhagic bullous lesions on the right foot, associated with inflammatory signs.

Because of weakness in the dorsiflexors of her feet and toes, the patient had a high-stepping gait, lifting her knees to avoid dragging her toes on the floor.

Haematological investigations showed normocytic and normochromic anaemia, leucocytosis with neutrophilia, and elevated $\mathrm{C}$ reactive protein and erythrocyte sedimentation rate. Electromyography showed a common sciatic mononeuropathy. A skin biopsy of the knee lesion was performed and the
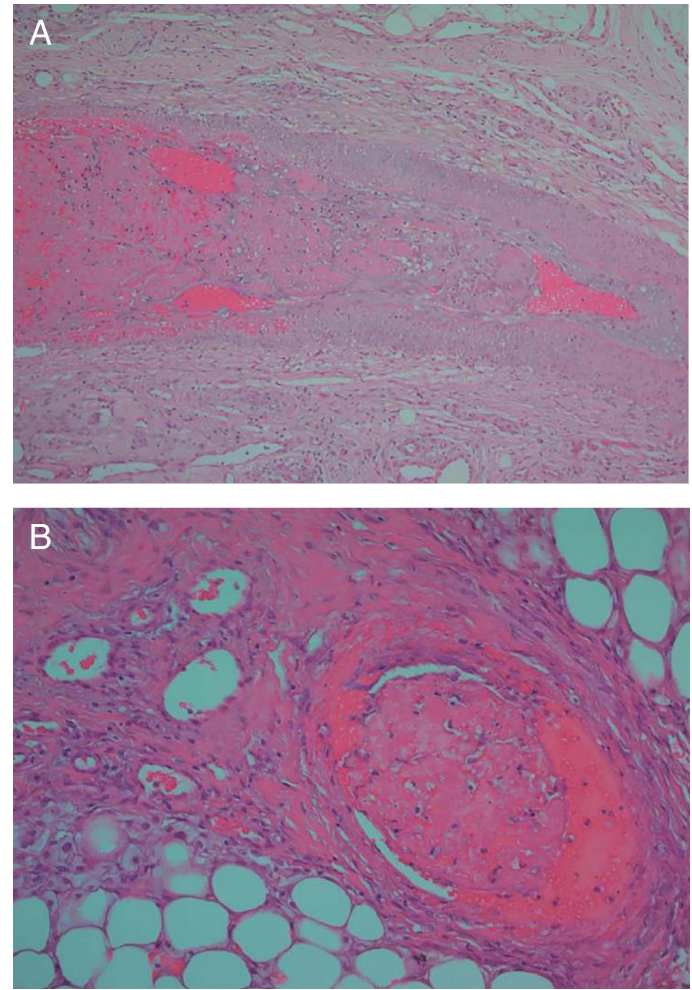

Figure 4 ( $A$ and $B$ ) Thrombosis and thinning of the artery wall are observed. 


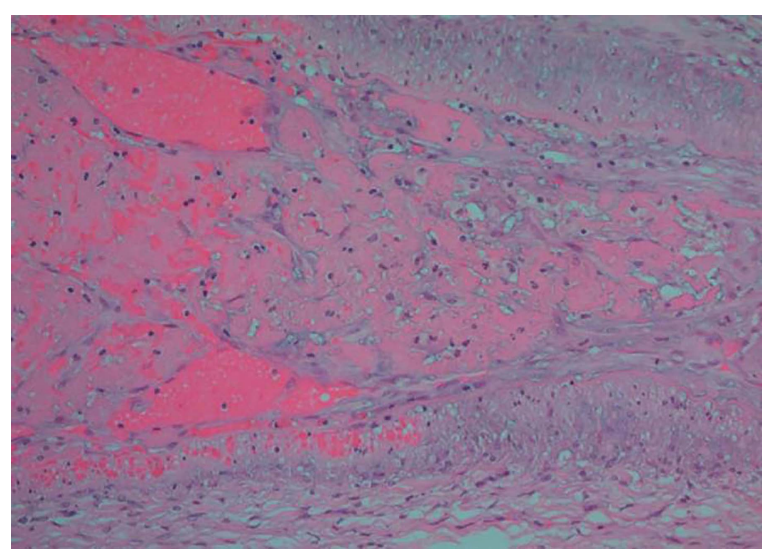

Figure 5 Medium-sized artery with focal inflammation of the wall.

histology of the lesion evidenced arteries with lumen filled with a thrombus, in early stages of resolution, reducing the remaining lumen by subintimal fibrosis. Thinning of the muscle wall and mild inflammatory infiltrate consisting of polymorphonuclear neutrophils and rare eosinophils with lesions associated with secondary panniculitis were also seen. There was no evidence of granuloma. These findings were consistent with polyarteritis nodosa (figures 4A, B and 5). No visceral involvement was documented. Corticosteroids ( $1 \mathrm{mg} / \mathrm{kg} /$ day $)$ were initiated followed by azathioprine $(50 \mathrm{mg} /$ day $)$ with a good outcome. The skin lesions resolved with the corticosteroid.

\section{Learning points}

- In polyarteritis nodosa, symptoms are the result of vascular damage in affected organs; in this case, skin lesions and mononeuropathy were the marks of disease activity.

- Histological evaluation of the lesions determines the diagnosis, allowing appropriate treatment.

Competing interests None.

Patient consent Obtained.

Provenance and peer review Not commissioned; externally peer reviewed.

\section{REFERENCES}

1 Brandt HR, Arnone M, Valente NY, et al. Medium and large vessel vasculites. An Bras Dermatol 2009;84:55-67.

2 Rodrígues JH, Cid MC. Polyarteritis nodosa. In: Diagnostic criteria in autoimmune diseases. Barcelona: Humana Press, 2008:87-93.

Copyright 2015 BMJ Publishing Group. All rights reserved. For permission to reuse any of this content visit http://group.bmj.com/group/rights-licensing/permissions.

BMJ Case Report Fellows may re-use this article for personal use and teaching without any further permission.

Become a Fellow of BMJ Case Reports today and you can:

- Submit as many cases as you like

- Enjoy fast sympathetic peer review and rapid publication of accepted articles

- Access all the published articles

- Re-use any of the published material for personal use and teaching without further permission

For information on Institutional Fellowships contact consortiasales@bmjgroup.com

Visit casereports.bmj.com for more articles like this and to become a Fellow 